\title{
REVERSE LOGISTICS IN THE DISPOSAL OF RESIDUAL LUBRICATING OIL
}

\section{Ednilton Tavares de Andrade}

Federal University of Lavras (UFLA), Engineering Dept., P.O. Box 3037, CEP 37.200-000, Lavras, MG, Brazil

\section{Márcia Eduarda Amâncio}

Federal University of Lavras (UFLA), Engineering Dept., P.O. Box 3037, CEP 37.200-000, Lavras, MG, Brazil

\section{Tammy Lima de Jesus}

Fluminense Federal University (UFF), Agricultural and Environmental Engineering Dept., CEP 24220-900, Niterói, RJ, Brazil

\author{
Renan Pereira Rezende \\ Federal University of Lavras (UFLA), Engineering Dept., P.O. Box 3037, CEP 37.200-000, Lavras, MG, Brazil \\ Corresponding Author. renanprezende@gmail.com
}

\section{Antônio Carlos Dutra de Sousa}

Fluminense Federal University (UFF), Agricultural and Environmental Engineering Dept., CEP 24220-900, Niterói, RJ, Brazil

\section{Fortunato Silva de Menezes}

Federal University of Lavras (UFLA), Exact Sciences Dept., P.O. Box 3037, CEP 37.200-000, Lavras, MG, Brazil

\begin{abstract}
With the ascending growth in car acquisitions worldwide, there is also an increase on environmental pollution. It is very important to control the various factors that have an impact on this situation. Therefore, this paper had the goal of promote an efficient reverse logistics system, aiming to reuse the residual car lubricant oil in bottles after being used. The analysis were made with the intent of establishing a proper treatment to inappropriate discarded oil and reinsert it in the market, contributing to the economic balance and to a sustainable development between society and companies. The impacts on environment by residual lubricant oil in used bottles were presented and the boundary layer after full oil drain was calculated. Samples were collected from a gas station in order to quantify the volume of the generated residual oil after the oil change, and also the time for full residual oil drain was measured. Results show that each $1 \mathrm{~L}$ used lubricant oil bottle has approximately $20 \mathrm{~mL}$ of unused residual oil.
\end{abstract}

Index terms: Oil disposal, sustainability, environmental impacts.

Received: March 26, 2018 - Accepted: October 16, 2018

\section{INTRODUCTION}

It is of utmost importance to preserve and assure ideal conditions to the environment. Today, society and companies have been preponderantly discussing ways to minimize impacts on the various ecosystems. The economic imbalance generated from the rapid growth in production and outflow of products to the market significantly contributes to the pollution of water resources and springs, the extinction of animal and plant species and in the misuse of non-renewable energy resources.

The unceasing search for higher comfort and well-being standards reflects on this economic imbalance. According to Giucci (2004), in Europe this started with the invention of cars in the late nineteenth century, that conquered the market and society's sympathy, becoming an object of necessity and desire for consumers. The bottles sold in gas stations containing residual oil are kept in appropriate spaces until being discarded by outsourced companies. However, in most 
cases this discard occurs in improper forms, prejudicing the environment.

As stated by Pinheiro et al. (2017), the main harmful contaminants present in residual lubricant oil are heavy metals, poly-chlorinated hydrocarbons (PCB) and poly-aromatic compounds (PAH), which are highly toxic to human health and can cause damage to the environment if not disposed and treated properly. Also, it is reported that waste lubricant oil is the most significant liquid hazardous waste stream in Europe. This demonstrates the impact that improper oil discard can have on the environment.

In Brazil, the Conama Resolution $\mathrm{N}^{\circ} 362 / 2005$ and $\mathrm{N}^{\circ} 450 / 2012$ requires that used or contaminated lubricant oil must be properly destined without any harm to the environment. A reverse logistics system must be adopted, according to Article 33 from the 12.305/2010 act from the National Policy of Solid Waste for lubricant oil and its bottles. Yet, there is also a concern on how to properly implement such system, for it is very complex and requires an efficient infrastructure to work as intended, as mentioned by (Demajorovic, 2015).

The objective of this work was to collect bottles of used lubricant oil in gas stations, and analyze and quantify the wastes generated in car oil changes. The necessary time to extract the residual oil from bottles was then measured. This paper also recommends a feasible solution to the lubricant oil wastes problem that, in this case, is a reverse logistics system.

\section{MATERIAL AND METHODS}

This study was conducted in São Gonçalo, state of Rio de Janeiro, in a gas station from which the samples (used lubricant oil bottles) were collected for research. The climate of the region is tropical, with summer having higher rainfall levels than winter. The city is classified as AW in the Köppen-Geiger climate classification system. The average temperature is $23.3^{\circ} \mathrm{C}$, and the average annual precipitation is $1257 \mathrm{~mm}$.

This study was an exploratory research because the addressed subject did not present results from previous studies with the same goals of this experiment. The goal of exploratory researches is to generate more information on the addressed subject and to provide easiness by limiting the topic to be studied. Since data was also collected to develop this experiment, this study can also be considered a descriptive research, which has the goal of register, analyze, sort and interpret facts without any interference from the researcher. The approach for this study was quantitative, using statistical methods to analyze the problem and then reach a conclusion.

\section{Method for information gathering and sample selection}

To carry out this research, thirty 1 liter bottles of F1 MASTER Ipiranga (20w40) car lubricant oil were collected, with API (American Petroleum Institute) performance specification SF, where "S" stands for Sparks, that is, spark plugs for gasoline, alcohol or CNG combustion engines, and the letter " $\mathrm{F}$ " refers to the overall quality of the additives found in the lubricant oil. The collected samples were taken to the Thermo-science Lab at UFF (Fluminense Federal University). The process was conducted in the following way: the 30 bottles were randomly selected for 3 distinct treatments, with a total of 10 samples per treatment. To determine the residual volume in each bottle, 10 graduated cylinders and 10 funnels were used to collect to residual oil remaining in the used bottles. The bottles were turned upside down on the funnel, that was fixed on top of the beaker. This way, the residual oil flowed through the funnel into the beaker. Figures 1 below illustrate the above mentioned arrangement and the lubricant oil bottle, respectively.

The samples were collected within a 6-day period. During that time, the content from samples 1 to 10 was analyzed for 2 days ( 48 hours), samples 11 to 20 for the next 2 days and samples 21 to 30 in the last 2 days. Each bottle was kept in a vertical position in order that the oil was fully drained during the 48 hours period (Table 1 ). Table 2 shows the start and end dates for each sample collection. 


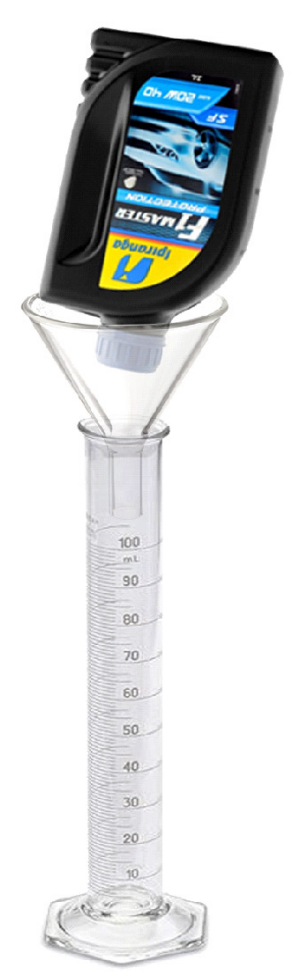

Figure 1: Illustration of the process of residual lubricant oil quantification.

Table 1: Description of the process, how the samples were separated between the three treatments.

\begin{tabular}{cc}
\hline \multicolumn{2}{c}{ Collecting method } \\
\hline Treatment & Number of samples \\
T1 & 10 bottles \\
T2 & 10 bottles \\
T3 & 10 bottles \\
\hline
\end{tabular}

Table 2: Collection period, start and end dates for samples collection.

\begin{tabular}{cccc}
\hline $\begin{array}{c}\text { No. of } \\
\text { bottles }\end{array}$ & \multicolumn{2}{c}{$\begin{array}{c}\text { Data collection period } \\
\text { Start }\end{array}$} & $\begin{array}{c}\text { Total analysis } \\
\text { time }(\mathrm{h})\end{array}$ \\
\hline 10 & $08 / 21 / 2013$ & $08 / 23 / 2013$ & 48 \\
10 & $08 / 23 / 2013$ & $08 / 25 / 2013$ & 48 \\
10 & $08 / 25 / 2013$ & $08 / 27 / 2013$ & 48 \\
\hline
\end{tabular}

Afterwards, the boundary layer from the residual oil inside the bottles after 48 hours of flow was measured. Equation 1 is used to obtain the perimeter of a circle, Equation 2 to obtain the thickness of the oil blade flowing from the bottle and Equation 3 is used to obtain the boundary layer of the oil (Halliday, 1997; White, 2006):
$P=2 \Pi R$

$\Delta l a m^{2} \geq \frac{\mu}{\rho} \cdot \frac{1}{g} \cdot V \min$

Clim = Alat. $\Delta$ lam

Where: $\mathrm{P}$ is the perimeter; $\Delta \mathrm{lam}$ is the thickness of the oil blade; $\mu$ is the dynamic viscosity; $\rho$ is the volumetric density; $g$ the gravitational force; Vmin is the minimum flow velocity; Clim represents the boundary layer; Alat is the lateral area.

\section{RESULTS AND DISCUSSION}

The results from this study are presented below. In the gas station where the bottler were collected approximately 850 liters of lubricant oil sold monthly. Residual lubricant oil obtained from 30 samples were collected and analyzed, that is approximately $3.5 \%$ from the total number.

The residual lubricant oil volume obtained from the collected samples are presented on Table 3.

If we scale these results to the total lubricant oil amount sold in one month by the gas station, a total of 27.16 liters of residual oil is generated each month. This number shows that the amount of oil being incorrectly destined into nature is significant because the pollution to soil and water springs due to improper dump of 1 ton of used oil is equivalent to the domestic sewage of 40 thousand people (AmbienteBrasil, 2001).

\section{Determining the necessary time for complete residual oil outflow from the bottles}

The procedure consisted of three phases, where treatments T1, T2 e T3 were observed for 48 hours each. The first and second day of each analysis were compared to check for volume changing in the beakers. After these observations, it was noticed that there was no significant change in volume after the first 24 hours of flow (Table 4). 
Table 3: Residual lubricant oil volume obtained from the collected samples, which resulted in a total of $972 \mathrm{~mL}$, or $0.97 \mathrm{~L}$.

\begin{tabular}{cccccc}
\hline Sample $n^{\circ}$ & $\begin{array}{c}\text { Residual } \\
\text { volume }(\mathrm{mL})\end{array}$ & Sample ${ }^{\circ}$. & $\begin{array}{c}\text { Residual } \\
\text { volume }(\mathrm{mL})\end{array}$ & Sample $\mathrm{n}^{\circ}$. & $\begin{array}{c}\text { Residual } \\
\text { volume }(\mathrm{mL})\end{array}$ \\
\hline 1 & 20 & 11 & 39 & 21 & 34 \\
2 & 24 & 12 & 23 & 22 & 22 \\
3 & 25 & 13 & 27 & 23 & 20 \\
4 & 35 & 14 & 35 & 24 & 41 \\
5 & 42 & 15 & 39 & 25 & 30 \\
6 & 37 & 16 & 22 & 26 & 37 \\
7 & 41 & 17 & 25 & 27 & 42 \\
8 & 33 & 18 & 42 & 28 & 32 \\
9 & 32 & 19 & 41 & 29 & 28 \\
10 & 41 & 20 & 35 & 30 & 314 \\
\hline Total & 330 & Total & 328 & Total \\
\hline
\end{tabular}

Table 4: Volume of residual oil collected every 24 hours for 2 days.

\begin{tabular}{|c|c|c|c|c|c|c|c|c|}
\hline \multirow[t]{2}{*}{ Sample } & \multicolumn{2}{|c|}{$\begin{array}{c}\text { Residual } \\
\text { volume }(\mathrm{mL})\end{array}$} & \multirow[t]{2}{*}{ Sample } & \multicolumn{2}{|c|}{$\begin{array}{c}\text { Residual } \\
\text { volume (mL) }\end{array}$} & \multirow[t]{2}{*}{ Sample } & \multicolumn{2}{|c|}{$\begin{array}{c}\text { Residual } \\
\text { volume (mL) }\end{array}$} \\
\hline & Day 1 & Day 2 & & Day 1 & Day 2 & & Day 1 & Day 2 \\
\hline 1 & 20 & 20 & 11 & 39 & 39 & 21 & 34 & 34 \\
\hline 2 & 22 & 24 & 12 & 23 & 23 & 22 & 22 & 22 \\
\hline 3 & 25 & 25 & 13 & 27 & 27 & 23 & 20 & 20 \\
\hline 4 & 32 & 35 & 14 & 35 & 35 & 24 & 41 & 41 \\
\hline 5 & 42 & 42 & 15 & 39 & 39 & 25 & 30 & 30 \\
\hline 6 & 37 & 37 & 16 & 22 & 22 & 26 & 28 & 28 \\
\hline 7 & 41 & 41 & 17 & 25 & 25 & 27 & 37 & 37 \\
\hline 8 & 33 & 33 & 18 & 42 & 42 & 28 & 42 & 42 \\
\hline 9 & 32 & 32 & 19 & 41 & 41 & 29 & 32 & 32 \\
\hline 10 & 41 & 41 & 20 & 35 & 35 & 30 & 28 & 28 \\
\hline Total & 325 & 330 & Total & 328 & 328 & Total & 314 & 314 \\
\hline
\end{tabular}

Determining the boundary layer of the remaining oil inside the bottle after 48 hours of flow

The table below presents the calculated values for the boundary layer of the remaining oil after the 48 hours flow (Table 5).

It is concluded that the necessary time for the complete residual oil drain is 24 hours. However, even after this period there will still be an oil film inside the bottle, called boundary layer, which won't be drained due to the acting vertical force on the liquid being extremely weak. Therefore, even with the complete residual oil drain, the amount of lubricant oil on the boundary layer is significant when considering the amount of bottles beings sold worldwide. It is also important to notice that, according to SABESP,
1 liter of oil can contaminate up to 25 thousand liters of water.

In the gas station, the used lubricant oil bottles are collected and sent to an outsourced company that are accredited by the National Petroleum Agency (ANP). The bottles are stored in plastic bags until collection. However, there is no treatment to the residual oil from the boundary layer remaining inside the bottles. Oftentimes the used bottles are stored without lid, which facilitates soil contamination and oil flow to water springs. The bottles are often kept in inappropriate places until collection.

There are approximately 38 thousand gas stations in Brazil. When considering this number, the amount of waste generated becomes even more expressive and certainly its eviction will entail in chronic harm to ecosystems. 
Table 5: Calculated values for the boundary layer of the remaining oil after the 48 hours flow.

\begin{tabular}{cccc}
\hline Calculation & Result $\left(\mathrm{m}^{3}\right)$ & Result $(\mathrm{L})$ & $\mathrm{T}\left({ }^{\circ} \mathrm{C}\right)$ \\
\hline Perimeter & 0.3162 & & 40 \\
$\Delta \mathrm{L}$ & $5.5406 \cdot 10^{-6}$ & 0.0055 & 40 \\
Clim & $25.7703 \cdot 10^{-6}$ & 0.0258 & 40 \\
\hline
\end{tabular}

\section{CONCLUSIONS}

This study results prove to be significant, showing the potential harm from the numerous bottles being discarded each day.

A reverse logistics system for used car lubricant oil bottles is used by the studied gas station. Outsourced companies collect these bottles and after a recycling process, the residual material is again integrated in the productive chain, being reutilized.

Yet, results show that even after oil outflow for 24 hours, a boundary layer, unable to be drained, still remains inside the bottles. As a solution, there should be a complete removal from this remaining oil before discard because when considering the total amount of residual oil being generated daily, it represents a great impact on environment degradation.

It is also suggested that gas stations adopt the Jet Oil technology, as it is a car lubricant oil change system where oil is stored in tanks or barrels and is sold in bulk, preventing the usage of conventional bottles and its inevitable wastes.

\section{REFERENCES}

AMBIENTEBRASIL. Óleos lubrificantes. Revista meio ambiente industrial, ano VI, 31(30), 2001.

CLOCK, M. et al. Redução do impacto ambiental e recuperação de custos por meio da logística reversa: estudo de caso em empresa de distribuição elétrica. Produção em Foco, Rio Grande doSul, 1(1):101-123, 2011.

DACACH, C. M. Cenário mundial dos resíduos sólidos e o comportamento corporativo brasileiro frente à logística reversa. Perspectivas em Gestão \& Conhecimento, João Pessoa, 1(2):118-135, 2011.

DEMAJOROVIC, J.; SENCOVICI, L. A. Entraves e perspectivas para a logística reversa do óleo lubrificante e suas embalagens. Revista de Gestão Ambiental e Sustentabilidade, 4(2):83-101, 2015.
GIUCCI, G. A. Vida cultural do automóvel: percursos da modernidade cinética. Civilização Brasileira, Rio de Janeiro, 1(1):370, 2004.

PINHEIRO, C. T.; ASCENSÃO, V. R.; CARDOSO, C. M.; QUINA, M. J.; GANDO-FERREIRA, L. M. An overview of waste lubricant oil management system: Physicochemical characterization contribution for its improvement. Journal of Cleaner Production 150, 301-308, 2017.

HALLIDAY, D.; RESNICK, R. Fundamentals of Physics. 10.ed: Editora John Wiley \& Sons Inc,1997. 1448p.

SILVA, T. A. Descarte de óleos lubrificantes e suas embalagens: estudo de caso nos postos de gasolina e oficinas da cidade de Ituiutaba. Observatorium: Revista Eletrônica de Geografia, Minas Gerais, 3(7):101-114, 2011.

WHITE, F. M. Fluid Mechanics, 6. ed: Editora McGraw-Hill Companies, 2006. 